\title{
Neurath's debate with Horkheimer and the critique of Verstehen
}

[Final draft. Chapter forthcoming in Adam Tamas Tuboly (Ed), The History of

Understanding in Analytic Philosophy: Around Logical Empiricism, London: Bloomsbury.]

Andreas Vrahimis

Department of Classics and Philosophy

University of Cyprus

vrahimis.andreas@ucy.ac.cy

\begin{abstract}
During the late 1930s, the failed attempt at collaboration between the Frankfurt School and the Vienna Circle culminated in Horkheimer’s 1937 paper ‘The Latest Attack on Metaphysics'. Horkheimer ([1937] 1972), relying on a caricature of positivism as espousing an uncritical myth of the given, drew far-reaching conclusions concerning positivism's conservative prohibition of the radical questioning of appearances. Horkheimer (1940) later applied some of these criticisms to Dilthey's conception of Verstehen, while presenting Logical Empiricism as dismissing Dilthey's proposals nothing more than poetry. By examining Neurath's unpublished reply to Horkheimer, and drawing on Uebel's (2019) account of Logical Empiricism's stance towards Verstehen, this chapter will attempt to dispel Horkheimer's caricature. I will highlight a parallel between Neurath's attitude towards (i) claims about Verstehen in social science and (ii) Horkheimer's proposals for the use of Vernunft by a 'supra-scientific' Critical Theory. Neurath argues that once Horkheimer's objections to 'positivism' are reformulated in non-metaphysical terms, they point towards a genuine problem concerning science's relation to social praxis. For Neurath, the problem can be addressed from within (rather than, as Horkheimer would have it, from above) empirically-minded investigations in the history and sociology of science.
\end{abstract}

Keywords: Otto Neurath, Max Horkheimer, Verstehen, Wilhelm Dilthey

\section{Introduction}

Though the Nazis in Germany and the fascists in Austria had persecuted a number of individual philosophers, there were only two philosophical institutions that they targeted directly: the Frankfurt Institute for Social Research, and the Ernst Mach Society. As a result, during the late 1930s, almost all members of both the Vienna Circle and the Frankfurt School were refugees fleeing into exile. In 1936-7, in large measure due to the political situation they found themselves in, both institutions would negotiate an attempt at collaboration. ${ }^{1}$ The

\footnotetext{
${ }^{1}$ For more detailed studies of the relation between the Vienna Circle and the Frankfurt School, see Dahms (1994); Bowie (2000); O’Neill and Uebel (2004, 2018); Reisch (2005, 121-125); Wheatland (2009, 115-121);
} 
attempt, led by Max Horkheimer and Otto Neurath, would fail, resulting in Horkheimer's well-known critique of positivism in his 1937 article "The Latest Attack on Metaphysics".

At its outset, this chapter will look at the details of Horkheimer's 1937 article, analyzing some of the arguments Horkheimer develops against what he presents as Logical Empiricism's newest variety of 'scientism' and 'positivism'. Horkheimer claimed that Logical Empiricism was committed to the view that all knowledge is derivable from valuefree facts immediately given to the senses. Opposing this view, Horkheimer proposed a critical tribunal of Reason that would further probe behind the givenness of facts, and into the social activity that conditions them. Horkheimer later applied some of his 1937 arguments against positivism and its myth of the given in developing a critique of Dilthey's psychological conception of Verstehen in 1940. Despite accusing Dilthey of being a positivist, Horkheimer nonetheless misrepresents Logical Empiricism as providing the main argument against his conception of Verstehen. In fact, as this chapter will show, Horkheimer's portrayal of Logical Empiricism, both in 1937 and in 1940, is in large measure a caricature. $^{2}$

In the final parts of this chapter I will question Horkheimer's portrayal of the Logical Empiricist response to Verstehen, in light of Uebel's (2019) recent reconsideration of Neurath. I will examine Neurath's responses to Dilthey and Sombart, and compare them with Horkheimer's critique of Verstehen. As Uebel (2019) shows, Neurath's strategy for addressing claims about Verstehen is to rephrase them using non-metaphysical terminology. Neurath parallels this strategy towards Verstehen when he argues that once Horkheimer's objections to Logical Empiricism are reformulated in empirically-minded terms, they point towards a genuine problem concerning science's relation to social praxis. As I will show, for Neurath, the problem can be addressed within empirically-minded investigations in the history and sociology of science (rather than, as Horkheimer would have it, from a standpoint 'above' science). I will conclude by showing how, in Neurath's responses both to metaphysical conceptions of Verstehen and to Horkheimer's conception of critical Vernunft, Neurath defends Unified Science against metaphysical 'separatist' tendencies.

\section{Horkheimer against positivism}

Chase and Reynolds (2011, 31-34); Samios (2012); Turner and Factor (2014, 224-225); Dewulf (2017); Vrahimis (2020a).

${ }^{2}$ Dilthey's conception of Verstehen is discussed in detail by e.g. Makkreel (1996, 247-272), while a defence against common misportrayals by Dilthey's critics has been undertaken e.g. by Harrington (2001). 
Horkheimer's 1937 article portrays his contemporary philosophy as divided between two poles: 'metaphysics' and 'scientism'. ${ }^{3}$ In attempting to define the dichotomy, Horkheimer draws up a genealogy tracing these two elements back to Descartes' dualism. In Horkheimer's view, Descartes attempted to disenchant scientific enquiry into the res extensa, while at the same time opening a metaphysical path towards retaining a mental excess which cannot be disenchanted (Horkheimer 1937/1972: 134-35). This Cartesian enterprise would give rise to the tensions that eventually evolved into the polarization Horkheimer diagnoses within his contemporary philosophy. Horkheimer describes this polarization as follows:

\begin{abstract}
Although the formulations of science now offer the most advanced knowledge of nature, men continue to use obsolete forms of thought long discarded by scientific theory. ... It turns out, however, that many of these ideas are not merely superfluous, but also meaningless. Notions of absolute space, absolute time, and other metaphysical categories have been proved untenable. In addition, the doctrines of substance, causality, the soul, the mind-body relation, at least in their traditional form, have come into conflict with modern scientific methods. Yet, for all that, the pattern of ordinary thinking has not changed. This fact is really the projection of a contradiction that has persisted throughout the modern era. (Horkheimer 1937/1972: 133-34)
\end{abstract}

Horkheimer thus sets out by plainly stating that some of the basic areas within traditional metaphysics have been superseded by the advances of science. In this way, the lineage which derives from Descartes is seen by Horkheimer as reaching an impasse in his contemporary philosophical scene's division between metaphysics and scientism. Horkheimer clarifies that what he takes to be regressive metaphysics is, since the First World War, represented by "romantic spiritualism, Lebensphilosophie, and material and existential phenomenology" (1937/1972: 136). What unifies all these strands of philosophy is, in Horkheimer's view, their shared insistence on retaining the various categories which science has rendered redundant.

Horkheimer sees his contemporary metaphysicians as radicalized by comparison to their earlier modern predecessors. In Horkheimer's view, the "Cartesian solution" (1937/1972: 135) of substance dualism enabled earlier metaphysicians to draw a sharp distinction between their field and scientific endeavors. Nonetheless, as science rendered metaphysical categories more clearly obsolete, more and more strain would be put onto the conflict between science and metaphysics. According to Horkheimer, during and after the First World War this would lead to the following bifurcation in philosophy:

\footnotetext{
${ }^{3}$ Horkheimer uses the term 'Szientivismus', which has been translated into English as 'scientivism'; I will avoid this translation, using in its place the more common term 'scientism'.
} 
The various attempts at harmonization fall into two extremes. One is the statement that science is the only possible form of knowledge and that the last traces of metaphysical thought must give way before it. The other is the deprecation of science as a mere intellectual technique answering to subordinate considerations of human existence. True knowledge, it is urged, must emancipate itself from science. (Horkheimer 1937/1972: 136)

In other words, Horkheimer sees the latest rendition of metaphysics as radicalized insofar as it has become overly skeptical about the value of science. Horkheimer connects this skepticism about science with a reactionary political attitude, contending that "postwar metaphysics paved the way intellectually for the authoritarian system of government in Germany" (1937/1972: 139). On the opposite pole, according to Horkheimer, stands a reaction to such skepticism which seeks to eliminate metaphysics. Horkheimer calls this reaction 'scientism'.

Scientism, which is the main target of Horkheimer's critique in 1937, is exemplified by 'positivism'. Its latest manifestation in the post-war philosophical scene to which Horkheimer is responding is 'logical empiricism', which Horkheimer refers to as a "neopositivist mode of thought" (1937/1972: 139). ${ }^{4}$ In brief, positivism for Horkheimer is equivalent to the view that there is no possible object of knowledge outside empirically acquired knowledge. As Horkheimer sees it, due to its philosophical opposition to metaphysics, positivism thereby also happened to misguidedly attract "wide circles opposed to fascism" (1937/1972: 139).

Horkheimer's typology is an account of manifold divisions that fold into a dichotomy between the Frankfurt School and a number of other philosophical schools. But where is the Frankfurt School positioned in relation to its rivals? At first glance, Horkheimer seems to suggest that he is paving a path between two poles which the Frankfurt School is to navigate. Their path is one that will avoid falling back into traditional metaphysics, without thereby committing the scientistic error of limiting the knowable to supposedly value-free empirical knowledge of a given. In other words, Horkheimer's presentation implies that the Frankfurt

\footnotetext{
${ }^{4}$ Horkheimer uses the term 'Logical Empiricism' (and only once "logical positivism" (1937/1972: 185) and "neopositivis[m]" (1937/1972: 139)) to describe the work of Vienna Circle (as well as, misguidedly, Russell's and Wittgenstein's); in Horkheimer's view, Logical Empiricism is a brand of 'positivism' and a representative example of 'scientism'.
} 
School was set to programmatically avoid the 'parting of the ways' that Friedman (2000) sees as enacted between Heidegger and Carnap (1931/1959). ${ }^{5}$

Horkheimer's (1937/1972) main philosophical objections to Logical Empiricism (from which a series of political criticisms follow) are addressed against what he construes as its positivistic reliance on a conception of givenness to the senses. ${ }^{6}$ In Horkheimer's critique, 'positivism' (as exemplified by Logical Empiricism) must subscribe to a myth of the given, according to which value-free facts are somehow immediately grasped by the senses. There are two aspects of his version of the myth of the given that Horkheimer focuses on in his objections.

First of all, according to Horkheimer, an essential characteristic of 'positivism' is that it prohibits any further probing concerning the givenness of facts. In Horkheimer's view, positivism thus sets too strict a limit on critical inquiry. In his conception of positivism, any scientific attempt at studying what "lay before or behind individual facts and their interrelations" (1937/1972: 154) would go beyond the bounds of sense. Horkheimer's strategy for resisting this limitation is, like various subsequent post-positivist critics of the Vienna Circle (see Dahms 1994: 58), to relativize givenness by pointing to the continuously changing historical and social forces which shape our senses, as well as our practices of "the selection, description, acceptance, and synthesis of facts" (1937/1972: 145). Thus what the positivist takes to be observational facts, constitutive of scientific knowledge, are already conditioned by what Horkheimer calls "social praxis" (1937/1972: 154). Horkheimer insists that the positivists' restrictions on meaningfulness necessitate this blind spot concerning the socio-historical conditioning of facts. Horkheimer insists that in order to discover this, critical inquiry must necessarily investigate beyond mere facts as they are given to the senses.

Of course, apart from facts given to the senses, there is another element that is crucial to logical empiricism. In Horkheimer's account, Logical Empiricist epistemology allows for the systematic logical "arrangement and rearrangement" $(1937 / 1972,145)$ of given facts. Horkheimer even criticizes the 'positivist' account of science for overestimating the significance of such rearrangements. He notes that for the positivist

it matters not what facts are selected from the infinite number that present themselves. He proceeds as if the selection, description, acceptance, and synthesis of facts in this society have

\footnotetext{
${ }^{5}$ Though he does not explicitly state this, Horkheimer's article at least indirectly responds to Carnap's critique of Heidegger. In fact, following Adorno's recommendations, Horkheimer even deleted his mention of Heidegger by name from an earlier draft of his paper; see Dahms (1994: 122-23); Vrahimis (2020a). ${ }^{6}$ A more extensive analysis of Horkheimer's arguments is offered by Vrahimis (2020a).
} 
neither emphasis nor direction. Science is thus treated like a set of containers which are continually filled higher and kept in good condition by constant repair. This process, which was previously identified with the activity of the understanding, is unconnected with any activity which could react on it and thereby invest it with direction and meaning. Everything designated ... by materialism, as social practice and conscious historical activity, is related to science essentially as objects of observations and not as constitutive interests and directive forces, insofar as empiricism concedes them to be conditions of knowledge at all. (Horkheimer 1937/1972: 145)

Thus in the Kantian terminology Horkheimer (1937/1972: 145, 156, 158) employs, the Logical Empiricists conceive of science as consisting of facts discovered by sensation, on the one hand, and their conceptual arrangement by the understanding on the other. What is missing from Logical Empiricism, in Horkheimer's Kantian picture, is the faculty of Reason (1937/1972: 152, 156-157, 186). Horkheimer appeals to Reason (Vernunft), in the Kantian sense, as that faculty which allows for a further probing into the social practices which, qua "constitutive interests and directive forces" (1937/1972: 145), condition sensation.

Horkheimer's proposal for such further probing involves taking an interdisciplinary critical standpoint. In Horkheimer's view (1937/1972: 186), this standpoint is neither metaphysical, in the sense of being autonomous from scientific inquiry, neither is it scientistic, in the sense of being limited to given facts and their logical ordering. Critical Reason, in Horkheimer's view, must be allowed to rise above the individual sciences in order to question the social praxis which underlies what has uncritically been taken as given to the senses.

Secondly, according to Horkheimer, the positivist myth of the given is tied to a conception of facts as value-free which he considers problematic. ${ }^{7}$ If facts are conditioned by social praxis, as Horkheimer thinks, this further implies that they are value-laden. In Horkheimer's account, the very idea of value-free science is itself value-laden. The conception of science as value-free unavoidably leads to a relativistic outlook, as exemplified in the work of Neurath (Horkheimer 1937/1972: 165). ${ }^{8}$

Relativism has various dangerous political implications, according to Horkheimer (1937/1972: 165). He argues that the common correlation between relativism and liberalism is misconceived. He illustrates this with cases in which relativism had also been instrumentalized by brands of authoritarianism. Horkheimer (1937/1972: 165) cites

\footnotetext{
${ }^{7}$ A year before Horkheimer's 1937 article, and based on a very selective reading of the early Schlick, Marcuse (1936/1968, 64-66) had already briefly sketched this criticism of the 'one-dimensional' (47) positivist emphasis on value-free facts. Marcuse (70-71) appeals to the Marxist critique of Erscheinungsform in objecting to Schlick's rejection of the metaphysical distinction between essence and appearance

${ }^{8}$ But see Uebel's (1992: 295-301) answer to Horkheimer's charges; Uebel explains how normative questions could be addressed from within Neurath's reflexive framework for Unified Science. See also Uebel 2020.
} 
Mussolini's championing of relativism as a case in point, and even draws comparisons between Mussolini and Neurath in this regard. Horkheimer also draws various other farreaching political conclusions from his portrayal of positivism as bound to the myth of the given. According to Horkheimer, positivism's upholding of the myth of the given entails that it is bound to a type of conservatism prohibiting the radical questioning of appearances. ${ }^{9}$ From there, he leaps to an identification of positivism with the silencing of critical Reason, and even to the declaration of the compatibility of positivism with authoritarianism.

Partly due to his stated avoidance of dwelling "on the shades of differences among its adherents" (1937/1972: 141), Horkheimer's critique involves a number of stereotypes about Logical Empiricism that are now easily demonstrable as false (see also Vrahimis 2020a). For example, Horkheimer's central argument concerning the commitment of positivism to the myth of the given seems to simply ignore the disagreements between the Vienna Circle's members on precisely this topic in the context of the protocol-sentence debate (see Uebel 1992: 295-301; 2007). Perhaps more pertinent to our discussion in this chapter is Horkheimer's misidentification of positivism with a kind of very strict "physicalism" (1937/1972: 146) and "behaviourism" (1937/1972: 149-150, 152-153), to which I shall return in what follows.

Based on this straw man, Horkheimer proceeds to claim that, despite being seen at the time as one of the main "intellectual weapons against the totalitarian frenzy" (Horkheimer 1937/1972: 140; see also Jay 1996: 17), positivism was somehow "as securely bound as metaphysics to the established order" (1937/1972: 140). ${ }^{10}$ Having conceived of the positivist strictures on meaningfulness in the manner outlined above, Horkheimer can thus conclude that a description and critique of social praxis lies beyond such strictures. As Horkheimer sees it, the positivist is thus confined to the position of being unable to distinguish between the nonsensical metaphysics that support authoritarianism, and its non-positivist critics:

\footnotetext{
Harmony and significant existence, which metaphysics wrongly designates as true reality as against the contradictions of the phenomenal world, are not meaningless. Powerful economic forces welcome a philosophy that professes not to know what to make of these conceptions and for that reason prefers to stick to facts; a philosophy that resolves not to make any essential
}

\footnotetext{
${ }^{9}$ O'Neill and Uebel $(2018,152)$ contend that the divorcing of reason from action which Horkheimer began to defend during the 1930s would eventually lead to 'the conservative political quietism of Horkheimer's postwar work' (152).

${ }^{10}$ Marcuse (1936/1968), who also saw positivism as serving 'the interest of small and powerful economic groups' (66), had nonetheless conceded a 'critical tendency' (66) which distinguishes positivism from metaphysical dogmatism and the 'regressive social interests' (66) it serves to bolster.
} 
distinction between the conspiracy of brutal despots against all human aspiration to happiness and freedom, on the one hand, and the struggles to defeat these tyrants on the other; a philosophy that reduces the two to the abstract concept of the "given" and even glorifies such conduct as objectivity. (Horkheimer 1937/1972: 178)

It is in this way that Horkheimer is able to contrast his caricature of positivism with his own position, which becomes attentive to social praxis by breaking away from the positivist strictures, while nonetheless avoiding falling back into the errors of traditional metaphysics.

As already noted, the politically conservative nature of positivism is contrasted by Horkheimer with his own conception of critical Reason, which was to guide the Frankfurt School's endeavors under his leadership. Horkheimer calls for a kind of meta-scientific theoretical endeavor that is free from the limitation of being derivable from the given, and thus is able to somehow approach the social praxis that conditions givenness. In "The Latest Attack on Metaphysics", this is conceived as being able both to subvert authoritarian metaphysics and also to critically react to empirical science. The crucial question at stake here for Horkheimer is whether it is possible to meaningfully develop such a critical metascientific standpoint without reverting to traditional metaphysics and its deprecation of science. ${ }^{11}$ Is it not the case that any account of social praxis will inevitably rely on some empirical observations? If this is admitted, then would not a less strict version of positivism (i.e. something other than the caricature painted by Horkheimer) be able to recognize such an account as meaningful? If not, then how can Horkheimer even know that his position differs from traditional metaphysics? It seems, however, as I have shown above, that Horkheimer's conception of this meta-scientific enterprise is reliant on an argument against a 'positivist' straw man, caricatured in a way which none of its adherents, and especially not his interlocutor Neurath, actually upheld. Before returning to this issue, I will now examine how Horkheimer's critique of positivism informed his later reception of Dilthey.

\section{Horkheimer on Dilthey, Verstehen, and logical empiricism}

In 1940, three years after the attempted collaboration between the Frankfurt School and the Vienna Circle had failed, Horkheimer published one of the clearest articulations of his views on Verstehen in "The Relation between Psychology and Sociology in the Work of Wilhelm

\footnotetext{
${ }^{11}$ In his correspondence with Neurath, Horkheimer (2007: 125) admits that he is unable to produce a criterion which would justify claims made from this meta-scientific enterprise. Horkheimer nevertheless goes on to note that this is consistent with the main thrust of his work, which had been "trying to demonstrate the extent to which the required criterion can't be specified, particularly for the most decisive problems" (2007: 125). See also Vrahimis (2020a).
} 
Dilthey". Dilthey is among the various philosophers of his time who had insisted on drawing a strict separation between the Naturwissenschaften and Geisteswissenschaften. This was, as we shall see in more detail later, a thesis which would come under attack by various philosophers associated with the Vienna Circle, including perhaps most prominently Otto Neurath.

Given this critical attitude by the Vienna Circle, it is interesting to see that Horkheimer's 1940 paper presents Dilthey's conception of Verstehen as part of an overall alignment with a positivistic conception of scientific methodology. Throughout his article, Horkheimer (1940: 430, 432-434) portrays Dilthey as committed not only to a positivist methodology for science, but also specifically to a "denunciation of metaphysics" (1940: 433). According to Horkheimer, Dilthey had understood the cultural sciences (of which history was the most central for his goals) as reducible to the science of psychology. ${ }^{12}$ In Horkheimer's account, Dilthey conceives of the split between the Naturwissenschaften and Geisteswissenschaften in psychological terms, i.e. as pertaining to the difference between what Carnap would later call autopsychological and heteropsychological observations. ${ }^{13}$

\footnotetext{
The natural sciences are engaged in a systematic determination and classification of the facts given by sense perception in their space-time relationships. Cultural sciences have to deal with the same objects. Reality is not divided into nature on the one hand, and mind on the other. Cultural sciences have to deal with the same reality under another specific aspect. Certain objects in nature compel us to regard them as the expression of life past or present, and we are able to know their true character from an understanding of what we ourselves are. We must go back from them to our own life. (Horkheimer 1940: 433-434)
}

Horkheimer thus sees Dilthey as arguing that both the Natur-and the Geisteswissenschaften make claims about different aspects of the same reality. Horkheimer makes it clear that he sees the division Dilthey draws as purely methodological, and rejects the thesis that it may involve a metaphysical distinction between mind and matter. The Diltheyan methodological division, in Horkheimer's account, is not incompatible with the positivist strictures which he presents Dilthey as upholding, i.e. the limitation of what is known to what is given to the senses (which, as we have seen, Horkheimer also attributes to the Logical Empiricists). Both the natural and the cultural sciences have empirical content, though the types of experiences

\footnotetext{
12 On Dilthey's conception of psychology, see Feest 2007.

${ }^{13}$ See Uebel (2019: 3-4). On Carnap's dialogue with Dilthey, see e.g. Damböck $(2012,2017)$ and Dewulf (2017).
} 
involved in each are different. Only the latter involve the types of experiences that Dilthey categorized under the heading of Verstehen. Horkheimer (1940: 434) explains that Diltheyan Verstehen is not to be thought of as some mystical irreducible intuition (of the type that we find e.g. in Bergson). Rather, as Horkheimer (1940: 434) puts it, "Dilthey insisted that a basic scientific analysis of all individual data and relationships must precede understanding". Horkheimer thus does not, at this point in his analysis, see a clash between Dilthey's methodological account of the Geisteswissenschaften and his overall commitment to positivism.

Horkheimer appears to accept that Dilthey's account of Verstehen makes a valuable contribution to the methodology of the cultural sciences, but only insofar as it is acknowledged that it faces certain limitations. Thus Horkheimer's criticism does not mainly focus on rejecting Dilthey's psychological methodology for the cultural sciences, but on highlighting what is omitted by its application. Horkheimer even goes on to chastise Dilthey for precisely the same reasons he attacks the Logical Empiricists, namely for subscribing to the myth of the given. Horkheimer accuses Dilthey of insisting in the "unfounded belief that valid insight must confine itself to the realm of the immediately given" (1940: 437), and as a result setting too strict a limit on what can be known through the science of psychology, and by extension through the cultural sciences. ${ }^{14}$ Horkheimer directs against Dilthey one of the main criticisms that he had also directed against the Vienna Circle, namely that by buying into the myth of the given, he is bound to a kind of individualism which inevitably fails to account for social phenomena and for the supra-individual "worldly character of the human spirit" (Horkheimer 1940: 437).

Horkheimer thinks that Dilthey's individualist psychologism thus fails to account for the sphere of the "objective spirit" (1940: 442) at the level of theory. Horkheimer argues, however, that Dilthey brings 'objective spirit' into the picture in the guise of specific phenomena which he falsely presents as if they were purely subjective. Horkheimer sees this problem in Dilthey's position as the result of a contradiction between Dilthey's positivistic theoretical commitments and his concrete analyses of specific historical phenomena. Horkheimer sees the latter as bringing in social phenomena through the back door, so to speak. For example, Horkheimer points out that Dilthey's psychologico-historical analyses of

\footnotetext{
${ }^{14}$ The other case of subscribing to the myth of the given Horkheimer mentions here is not that of Logical Empiricism, but Bergson (1940: 437; see also p. 435). Elsewhere, both Horkheimer (e.g. 1933/1972: 40) and Adorno (1970/2013: 46) argued that Bergson's position concerning the immediate givenness of data to the senses amounts to a type of positivism. However, Bergson's appeal to the immediate givenness of intuitive knowledge was heavily criticized by both Schlick and Carnap; see e.g. Uebel 2007, 74-79.
} 
specific artists' lives and work involve extensive discussions of tendencies in their contemporary art world, or that when Dilthey "speaks of a Roman he draws in Roman law and Roman imperialism as real forces in the soul of the Roman citizen" (1940: 443). Thus his psychological analyses of purportedly 'subjective' phenomena contain discussions of social phenomena disguised as lived experiences. According to Horkheimer, due to Dilthey's unwarranted assumption of positivism (and thereby individualism), what is missing from his project is an explicit targeting of such social phenomena, which are indispensable from any analysis of history.

Confusingly, though Horkheimer admits that Dilthey had a positivistic orientation in his conception of Verstehen, he also mentions Logical Empiricism as giving rise to the main form of objection to such a conception:

\begin{abstract}
If Dilthey is right, a large part of our knowledge depends upon the inner richness of the individual, who strives for such knowledge. The act of knowing, in Dilthey's own words, comes close to the artistic process. In this case not a few modern methodologists would strike this whole section of knowledge from the realm of science and assign it to poetry, somewhat after the fashion of the logical empiricists. In economics they would like us to limit ourselves to mathematics, in human psychology to experiments with the tachystoscope or similar apparatus. But if these critics are right, a sphere of decisive experience would thus fall outside the range of scientific activity.
\end{abstract} (Horkheimer 1940: 434-35)

In other words, Horkheimer both thinks that Dilthey sets too strict a limit on what is knowable by espousing the positivistic myth of the given, and also that his positivist critics set too strict a limit to what is knowable by espousing a positivistic myth of the given that undercuts even Dilthey's notion of Verstehen. Horkheimer seems, at least indirectly, to further append to his earlier caricature of Logical Empiricism the above claims concerning the methodology of economics and psychology, for which he adduces no evidence. ${ }^{15} \mathrm{He}$ is nonetheless perhaps more circumspect than in his earlier work, insofar as he does not talk of the logical empiricists themselves but of 'a few modern methodologists' who hold such beliefs 'somewhat after the fashion of logical empiricists' (Horkheimer 1940: 434).

\title{
4. Against the caricature: Uebel on Neurath's response to Verstehen
}

\footnotetext{
${ }^{15}$ Such caricatures of 'positivism' become more and more prominent in later works of the Frankfurt School, escalating during the 1960s into the Positivismusstreit; see Dahms (1994).
} 
For the purposes of this study, what is most interesting about Horkheimer's (1940) article is its take on the Logical Empiricist critique of Verstehen. Such common misconceptions of Logical Empiricism have often resulted from inadequate attention paid to the detail of their work. Similar views to those presented by Horkheimer (1940) have often been falsely supposed to follow from some of the other features of Horkheimer's (1937/1972) earlier caricature concerning the Vienna Circle's commitment to crudely reductionist forms of behaviorism and physicalism. I will not here attempt to address this topic in connection to Logical Empiricism in general, but will focus on Neurath, who had been in debate with Horkheimer.

Uebel's recent work $(2010,2019)$ has reconsidered Neurath's critique of Verstehen by questioning whether he upheld reductionist behaviorist and physicalist views. ${ }^{16}$ Uebel (2019) concedes that at first glance the writings not only of Neurath, but also of Carnap and other members of the Vienna Circle, may deceptively appear to justify Horkheimer's view that they are committed to a reductive physicalism and behaviorism. ${ }^{17}$ This is insofar as 'behaviorism' and 'physicalism' make frequent appearances as emic terms to describe positions defended by, and even identified with, Logical Empiricism. Nonetheless, further scrutiny allows us to dispel the caricature.

The Logical Empiricists' apparent championing of 'behaviorism' and 'physicalism' often appeared in the context of their polemicizing against various rival philosophers who had championed a demarcation between Natur-and Geisteswissenschaften. Dilthey is among the names Neurath discusses in criticizing this demarcation in his 1931 book Empirical Sociology. According to Neurath, although Dilthey

himself wished to avoid metaphysics, he inspired it greatly. Even those people who tend to be empiricist, bow before the 'humanistic sciences' and praise Dilthey's significant achievement which, however, lies in his concrete analysis and not in his theoretical investigations. His inclination towards classification has given ideological support to those who would like to avoid causal investigations in social matters. German sociology above all is shot through with ideas of Dilthey's, some grasped and some misunderstood. Just as in certain circles the scientific worldview is spreading ever more widely, so the leading academic sociologists in Germany are strongly metaphysical in outlook, or at any rate, they are far removed from any endeavor intended to further a unified science on a materialist basis. (Neurath 1931/1973: 356)

\footnotetext{
${ }^{16}$ In earlier works Uebel (1992: 295-301) and O'Neill and Uebel (2004) have addressed the inapplicability of Horkheimer's caricature to Neurath more generally.

${ }^{17}$ On Carnap's relation to Verstehen, see e.g. Uebel (2019) and Dewulf (2017). Dewulf (2017) argues that critics like Horkheimer and Cassirer did not, in the 1930s, consider Carnap's earlier Aufbau and its way of accommodating the method of Verstehen within its overall understanding of the Geisteswissenschaften.
} 
Neurath's account of Dilthey here displays some interesting parallels with Horkheimer's (1940) later analysis. ${ }^{18}$ Neurath values Dilthey's "significant achievement" insofar as, in agreement with Horkheimer, he acknowledges Dilthey's declared intention to avoid metaphysical tendencies in the cultural sciences. As shown above, Horkheimer had criticized Dilthey's theoretical framework for being unduly restrictive due to his espousal of positivism. By contrast, he thought that his concrete analyses overcame the strictures of positivist individualism by bringing in elements of social praxis disguised as psychology. Neurath reverses Horkheimer's critique of Dilthey when he favors the content of Dilthey's concrete analyses over the theoretical framework in which they are undertaken. ${ }^{19}$

Neurath criticized Dilthey's theoretical framework for allowing philosophers in his wake to leap to a metaphysical segregation of the 'humanistic' from the 'natural' sciences. Neurath (e.g. 1930, 44-45; 2020a, 245) attacked the metaphysical division between Naturwissenschaften and Geisteswissenschaften as a remnant of the Christian religious division between the earthly and the heavenly realms. Neurath (1930, 44-45) sees that in fields such as history and sociology, scholars have given refuge to religious and theological notions of the heavenly, attempting to rescue them from being brought back to earth by naturalistic explanations. ${ }^{20}$ The Weberian conception of Verstehen as a prerequisite for explanation even threatens to make such metaphysically-phrased religious notions indispensable for science. ${ }^{21}$ Such misuses of metaphysical nonsense would rely on Dilthey's notion of Verstehen, nonetheless divorcing it from the empirically-minded manner in which Dilthey drew its connection to natural science (which both Horkheimer and Neurath emphasize). Uebel (2019) demonstrates that Neurath's main criticisms of Verstehen are thus

\footnotetext{
${ }^{18}$ Horkheimer (1937/1972: 145, 152-53) was clearly aware of, and had commented on Neurath's Empiricism and Sociology. It is possible that a superficial reading of the more polemical claims made by Neurath in that book may have informed Horkheimer's caricature of the Logical Empiricist critique of Verstehen.

${ }^{19}$ Neurath expresses a very similar attitude in his reply to Horkheimer. There Neurath (1937: 14) clearly states his appreciation of the concrete sociological analyses undertaken by the Frankfurt School, which he sees as compatible with the Logical Empiricist conception of Unified Science. By contrast, Neurath criticizes various aspects of Horkheimer's theoretical framework. Horkheimer in turn had reciprocated by expressing, in private correspondence, his admiration for Neurath's concrete analyses (e.g. his paper on the standard of living (Neurath 1937b) or his work on ISOTYPE) while remaining critical of the Logical Empiricist theoretical framework (Dahms 1994: 178-79).

${ }^{20}$ Neurath $(2020 \mathrm{a}, 246)$ points out that even the common view of the social sciences as 'Geisteswissenschaften' is problematic, since they study processes to which the term 'Geist' would be admitted as inapplicable even by its proponents.

${ }^{21}$ See Uebel 2019, 6-8.
} 
directed not against Dilthey himself, but against various other figures in Dilthey's line of influence, such as Sombart or Spengler. ${ }^{22}$

Recent studies (e.g. Gabriel 2004; Damböck 2012, 2017; Dewulf 2017; Nelson 2018) have highlighted that Dilthey's work was at least partly influential on various Vienna Circle figures, including most prominently Carnap. This influence can best be understood in light of some fundamental differences between Dilthey and some of his followers. There are substantial philosophical differences between what Horkheimer sees as a positivistic bias in Dilthey, and the metaphysical tendencies of some of the philosophers in his line of influence. There was also a notable political difference between the former and the latter. While Dilthey himself was committed to a brand of democratic Enlightenment liberalism, ${ }^{23}$ many of the figures influenced by his work were politically reactionary. ${ }^{24}$ This political difference at least partly informed the Logical Empiricist reception of Dilthey's work (see Nelson 2018: 322). Indeed, in 1931, Neurath offers an analysis of how later metaphysical uses of Dilthey were connected to the state's power over academic appointments:

This advance of metaphysics becomes understandable if we take a look at those who hold such views. On the whole the representatives of metaphysically directed sociology are at the same time representatives of the ruling order. Most governments and other centres of power favor metaphysically inclined scholars, even theologizing ones, whereas they are mostly suspicious of anti-metaphysically inclined scholars, especially those who wish to establish this outlook in the field of sociology. Since the ruling bourgeois classes are more or less closely linked with clerical circles, and Christian priests generally defend the ruling order against revolution, a certain protection of the theological and metaphysical outlook seems probable from the outset. (Neurath 1931/1973: 356)

Despite their fundamental disagreements concerning the political dimensions of Logical Empiricism, Neurath seems here to be largely in agreement with the connections Horkheimer (1937/1972) draws between metaphysics and the authoritarian state. After all, by the 1930s

\footnotetext{
${ }^{22}$ Neurath also criticized Max Weber and Neo-Kantian philosophers such as Rickert and Windelband. It should here be noted that In responding to Spengler, Neurath did criticize another specific aspect of the late Dilthey's legacy, namely his metaphysics of world-views. Even here, however, Neurath should be understood as calling for a kind of empirical rehabilitation of Dilthey's conception of world-views, rather than rejecting it wholesale as metaphysical. In two recently translated articles, Neurath tackles the concept of worldviews in relation to his own brand of Marxism (Neurath 2020a), and in his critical response to Mannheim (Neurath 2020b). On the complex engagements of the Vienna Circle with Lebensphilosophie, see Vrahimis (2020c).

${ }^{23}$ On the middle class political and cultural history of $19^{\text {th }}$-century conceptions of Verstehen, see e.g. Phillips (2010); Arens (2010).

${ }^{24}$ Cooper (1996) has argued that, despite Dilthey's own liberal politics, his holistic conception of Verstehen was compatible with, and would even enable, later irrationalist fascist appeals to some purported organic unity of 'life'.
} 
the Vienna Circle had already fought various battles against academics (e.g. Othmar Spann) whose 'metaphysically inclined' and 'theologizing' views had sought to give respectability to various political positions (e.g. clericalism, Austrofascism, pan-Germanism, corporatism) that both the Frankfurt School and the Vienna Circle opposed (see e.g. Stadler 2015, 254; Romizi 2012; Scott 2020, 230-231).

Neurath's political opposition to the metaphysical interpreters of Dilthey informs his critical responses to the debate over Verstehen. Neurath did in fact explicitly target the idea that there is such a thing as an irreducible type of intersubjective "empathetic understanding, Einfühlung or Verstehen" (Uebel 2019: 1) which could provide a methodological backdrop exclusive to the Geisteswissenschaften. Horkheimer's diagnosis was thus at least partly correct: in response to such cases, Neurath polemicized against metaphysical claims about Verstehen by characterizing them as being mere poetry (e.g. Neurath 1931/1973: 357; see Uebel 2019: 7). Nevertheless, Horkheimer, like many others, was wrong in thinking that Neurath's critique of metaphysical statements covered all and any claims about Verstehen. According to Uebel (2019: 5), Neurath did not think that the concept of Verstehen itself was altogether meaningless. Neurath's objections were directed against a subset of claims employing this concept, namely the specific range of views that held Verstehen to be somehow unanalyzable and irreducible. ${ }^{25}$ It is precisely from such dubious premises that his contemporaries had leapt to the metaphysical separation between two types of science ('human' and 'natural') which Neurath targeted.

A consequence of such metaphysical views about Verstehen is that, due primarily to the language in which they are phrased, they mistakenly purport to preclude any type of empirical testing. By contrast, as Uebel (2019) shows, Neurath's proposal had been to probe deeper into such statements, clearing away their metaphysical components by showing how they can, upon further scrutiny, be rendered empirically testable. According to Neurath, "[w]hen the concept of Verstehen is analysed scientifically, then everything about it that can be communicated in words to somebody else turns out to be a statement about structure, just as in the natural sciences" (quoted in Uebel 2019: 6). In this way, Verstehen is reinstated in a non-metaphysical form. Neurath's goal was not to eliminate the statements of the 'human sciences', but rather to correct their mode of expression. A certain range of statements about Verstehen tends to systematically commit the error of employing metaphysical language. Neurath's aim was to show that the error can be avoided by carefully rephrasing statements in

\footnotetext{
${ }^{25}$ Cooper (1996) claims that Dilthey shares with later fascist tendencies the view that claims about Verstehen are irreducible.
} 
a way that renders them empirically testable (for example by rendering first-person introspective reports about conscious states into third-person protocols about such firstperson reports; Uebel 2019: 9-10.).

According to Uebel (2019), Neurath's position on Verstehen can be detected in the details of his various critical responses to a number of contemporary philosophers and social and cultural theorists. Neurath does often engage in excessive polemics, and misunderstands some of his targets' views. ${ }^{26}$ It is only once one looks past his polemical excesses and misunderstandings are cleared away that Neurath's intention in these debates comes into view. Neurath shows, in each case, how the relevant metaphysical claims about the autonomy of sciences based on Verstehen from other sciences can be cleared away, rendering nonmetaphysical, empirically testable claims about Verstehen part of his vision of a materialist Unified Science (see Uebel 2019: 7).

In connection to the debate with Horkheimer, an interesting case among Neurath's targets is that of Sombart. Neurath criticizes Sombart for moving away from the kind of individualistic psychological conception of Verstehen that we find in Dilthey, towards what he calls a 'noological', non-psychological conception. Sombart also provides us with a particularly good example of the aforementioned political dimension of the dispute, since he conceives of this distinction in nationalistic terms. He categorizes the psychological conception of Verstehen as part of 'Western' sociology, which he contrasts with 'German' sociology and its 'noological' conception. ${ }^{27}$ The latter involves an appeal to an objective "spirit [which] cannot be reduced to mind and [to] human culture [which] cannot be derived from elementary psychological drives" (quoted in Uebel 2019: 6). Sombart's is a clear case of how claims about Verstehen are transposed from empirically testable psychological claims (as we find e.g. in Dilthey) into what the Vienna Circle would condemn as metaphysical nonsense. Furthermore, the nationalistic usage to which Sombart puts his metaphysical nonsense exemplifies precisely the kind of political attitude that Neurath had wished to oppose. $^{28}$

Sombart's criticism of the individualistic psychological conception of Verstehen is to some extent similar to Horkheimer's critique of the limitations of Dilthey's individualism. Dilthey himself made use of the Hegelian terminology of 'objective Spirit' and, as we have

\footnotetext{
${ }^{26}$ For example, Uebel (2019: 6-8) shows that in his analysis of Max Weber Neurath exaggerates his influence by Rickert's metaphysics, missing the fact that Weber had in fact expressed his doubts about Rickert.

${ }^{27}$ See Uebel (2019: 6). In Sombart's account, Germany and its Kultur were differentiated from the merely technological civilizations of the 'West'; see also Vrahimis (2015: 89-90).

${ }^{28}$ A similar conflation between metaphysics and nationalist politics occurs in Spengler, who is elsewhere targeted by Neurath (1921/1973).
} 
already seen, Horkheimer (1940: 442-43) makes explicit reference to this element in objecting to Dilthey. Horkheimer notes that the "postulate, that the subjective mind can be rightly understood only in connection with the objective mind (using the Hegelian terminology), has not been fully worked out in his [i.e. Dilthey's] historical writings" (1940: 443). Though Sombart and Horkheimer were on very different sides of the political spectrum, their proposed criticisms of individualism, and their connected appeals to social phenomena (via the Hegelian notion of 'objective spirit') may appear here to lie philosophically quite close. In Sombart's case, it was easy for Neurath to detect his straightforwardly metaphysical attitude, denying that any type of empirical test would be possible for his proclamations about spirit. What about Horkheimer's claims about the possibility of grasping 'social praxis' through the use of critical Reason, while at the same time avoiding the pitfalls of metaphysics?

\section{Neurath's reply to Horkheimer}

Though at least obliquely relevant, the methods of Verstehen are not what is directly at stake in the case of Horkheimer's proposal for a critical approach to social praxis. Instead, Horkheimer's main disagreement with Neurath concerned the viability of pursuing some other type of non-empirical meta-science. In his reply to Horkheimer's 1937 article, Neurath summarizes Horkheimer's claims as follows: ${ }^{29}$

\footnotetext{
there is an extra-scientific method, which is based on everything that is scientifically established, and which can criticise the sciences in particular by exhibiting their historical position in a way that is foreign to the sciences." This standpoint, named by Horkheimer "dialectical" or "critical", goes beyond both the metaphysical, as well as the scientific; it was precisely the error of the "Scientivists" that they are "opposed to thought, whether it tend forward with reason, or backward with metaphysics" [Horkheimer 1937/1972: 186]. He takes himself to be defending Reason [Vernunft] against Empiricism, whereby, in the sense of traditional German philosophy, he distinguishes between Understanding [Verstand] — which he will not deny to Empiricism — and Reason [Vernunft]. (Neurath 1937a: 4). ${ }^{30}$
}

Thus it is Reason (in the Kantian sense already outlined above) that is, according to Horkheimer, the vehicle of that critical meta-scientific activity which may stand over and

\footnotetext{
${ }^{29}$ Neurath's reply remained unpublished between 1937 and 2011, when it was first made available in English translation (Neurath 2011).

${ }^{30}$ To avoid confusion it should be noted here that, as Neurath clarifies, the sense of 'Verstand' here is the Kantian one involved in Horkheimer (1937/1972), rather than the Diltheyan notion discussed in Horkheimer (1940).
} 
above empirical science. The main question which thereby arises for Neurath is whether Horkheimer's proposal concerning a critical perspective on the relation between scientific and social activity requires taking some irreducibly metaphysical a priori standpoint above science. In Neurath's view, the correct answer to this question is: no.

Neurath concedes that Horkheimer raises a question that is crucial for an empiricist understanding of science's social impact, and social activity's impact on science. Nonetheless, to reach the kind of valuable insight involved in Horkheimer's criticisms, his objections need to be reformulated in empirically testable terms. Neurath opens his attempt to undertake such a reformulation by pointing out that scientific activity is unavoidably a kind of social activity, the consequences of which are often not determinable by its agents. In Neurath's example (1937a: 3), a conservatively-minded scientist may unwittingly contribute to tomorrow's progressive social struggles. One possible non-empiricist response to this uncertainty could be to attempt to fix the possible relations between scientific and social activity through some aprioristic form of metaphysics. Indeed, Neurath sees Horkheimer as being in the line of influence of such metaphysical approaches, stemming from German Idealism. For the empiricist, however, this is not a viable option. It prematurely flees from the reality of empirical uncertainty into some realm of false a priori certainty (what Neurath elsewhere (e.g. 1921/1973) calls 'pseudorationalism'). Once a priori metaphysical speculation has been ruled out as a possible solution to the problem, it becomes clear how difficult it is to predict the future social consequences of scientific activity and vice versa. This, for Neurath, is a genuine problem which arises in a purely empirical manner, and which is of the utmost concern to the empiricist who has realized that there is no possible appeal to metaphysics that could resolve it. In other words, the problem that Horkheimer cites turns out to be much more serious than he himself takes it to be!

Horkheimer's preference for metaphysically charged terminology seems largely to be the reason preventing him from giving an adequate formulation of the problem he raises. Neurath detects metaphysical elements both in the language which Horkheimer uses to pose his question, and in the resulting attempt to answer it in a "supra-empiricist" (Neurath 1937a: 4) manner. While attempting to address a question which, Neurath argues, should be understood as arising within empirical science, Horkheimer's proposed solution appeals to some supra-empirical critical tribunal by Reason. Horkheimer's appeal to Reason, which is reached through the application of what Neurath sees as a poorly defined method of dialectics, promises to determine the manifold of relations that hold between scientific discovery and social praxis. 
Neurath thinks that Horkheimer is held back by traditional German philosophy's ways of posing and answering such questions in a priori terms. Neurath briefly states (1937a: 4, 13) that Horkheimer's views are traceable back to metaphysical terminology employed by the German Idealists, and points to Horkheimer's reservedly sympathetic references to "Hegel, Kant, the Neo-Kantians and Husserl" (1937a: 13) as evidence that this is the case. Horkheimer retains such metaphysical terminology not only in his conception of 'Reason', but also, for example, when he appeals to the 'essence' that is hidden beneath the mere 'appearances' that are given to the senses (Neurath 1937a: 16; see also O'Neill and Uebel 2004: 80-83).

In place of metaphysical appeals to an a priori meta-science, Neurath proposes what he sees as a viable empirical method for investigating the relation between scientific discovery and social praxis. This empirical method may be, for Neurath, pursued in examining the history and sociology of science. Horkheimer makes a number of claims concerning the history of empiricism, which seem to be, as Neurath sees it, proclaimed ex cathedra without empirical evidence. Instead, Neurath claims that:

\footnotetext{
If one interprets Horkheimer's emotional turns of phrase, his metaphorical and allegorical statements, and his metaphysical expressions, in an empirical manner as much as it is possible, one comes to serious problems [...] It would certainly be valuable to analyse these problems, which are also related to the status of empiricism, using concrete material from the last 100 years. A comprehensive historico-sociological account of the history of scientific Empiricism is a scientific desideratum; had it existed, one could more easily find out whether one or another of Horkheimer's metaphysically draped theses point to certain connections, which have so far escaped the notice of many empiricists - but even if such examination were to prove this, it would still be a long way from proving that Horkheimer's method is useful and that his metaphysical style is necessary. (Neurath 1937a: 24)
}

Thus, according to Neurath, determining the relation between scientific and social activity constitutes a project that is vital to an empiricist and materialist conception of Unified Science. Nonetheless, in Neurath's view the supra-empiricist method that Horkheimer approaches it with is questionable, if not simply redundant. Instead, according to Neurath, an empirical social scientific and historical approach to the role empiricism has played within the history of science provides a method of testing Horkheimer's claims (once they are correctly reformulated, avoiding metaphysical terminology). Neurath calls for a critical and reflexive standpoint that would be able to scientifically address the problems addressed by 
Horkheimer. Neurath refers to this standpoint as being within the "comprehensive scientific outlook" (1937a: 8) which the Unity of Science movement advocates. The proposed critique would thus come from within empirically-minded science, rather than from some impossible position above it. In this way it is possible to test whether Horkheimer's claims concerning the social effects of empiricism are true or false.

\section{Conclusion}

In conclusion, there is an interesting parallel to be drawn here between Neurath's criticism of Horkheimer's critical conception of Vernunft, and his views about Verstehen. As we have seen above, Neurath responded to statements about Verstehen by attempting to salvage their empirical content, while avoiding being misled into metaphysical errors through the misuse of language. Neurath's strategy in defense from Horkheimer's critique of 'positivism' (or at least a straw man thereof) runs parallel to this empirical rehabilitation of Verstehen insofar as it is an exhortation to separate the metaphysical chaff from the empirical grain.

Some of the views defended both by Dilthey's followers and by Horkheimer challenge, in different ways, Neurath's view of a Unified Science. Both institute different types of separation between different types of endeavors that Neurath would like to unify. In the case of metaphysical conceptions of Verstehen, the threat comes in the guise of a division within science, namely its separation into Naturwissenschaft and Geisteswissenschaft. Neurath's proposed rehabilitation of the metaphysical vocabulary engaged in the envisaged separation intends to pave a path towards meaningful communication between Natur-and Geisteswissenschaften within the framework of Unified Science. Horkheimer's Frankfurt School, on the other hand, threatens to create another type of division, namely that between scientific activity and the Critical Theory that purportedly stands above it (e.g. Horkheimer 1937/1972, 182-83; see Uebel 1992: 295). Neurath's clearing away of the metaphysical elements in Horkheimer's objections looks towards an integration of the Frankfurt School's critical project into the encyclopedic project of Unified Science. In both cases, Neurath resists the 'separatist' tendencies by proposing manners of empirically rehabilitating them, and thus making room for them within the wide scope of Unified Science. Neurath's strategy of rehabilitation involves showing how to avoid the employment of metaphysical language which had prompted such 'separatist' tendencies in the first place.

The critical aspect of such a project, i.e. what was often misconstrued as the goal of 'eliminating' metaphysical language, allowed for various caricatures to emerge, e.g. the one which we find in Horkheimer. Neurath (1937a: 8-9) is conscious of this when he notes in his 
reply that, though of course highly significant, the overcoming of metaphysics through the use of logical analysis is but a small aspect of the Logical Empiricist project. While Horkheimer's caricature focuses almost exclusively on limitations imposed by antimetaphysical strictures, Neurath's vision for Unified Science was inclusive and encyclopedic, and included reflexive and critical elements (see Neurath 1937a: 4-6). Contrary to the apparent implications of his infamous use of an 'index verborum prohibitorum' for metaphysical terms, Neurath did not seek to ban either claims about Verstehen, or critical reflection on scientific activity and its relation to social praxis.

Of course, though Neurath's strategies against Verstehen and against Horkheimer's Vernunft may be similar, their targets are not the same. The method of Verstehen, in Dilthey's metaphysically inclined followers, involves an explicit conception of a type of knowledge that purports not to be empirically testable. As we have seen, Neurath responds to this by showing how to rephrase the terminology involved so as to render the claims in question relevant to empirically testable statements. What Horkheimer attempts to develop, on the other hand, is not a special type of knowing (like that attempted by what he calls 'metaphysics'), but rather a type of reflection on the results of empirical science. ${ }^{31}$ This is how he claimed to avoid both 'metaphysics' and 'scientism'. Thus Neurath's response, in addition to showing which parts of Horkheimer's critique may be reformulated so as to be rendered compatible with Logical Empiricism, also needs to show why his own view of an immanent critique of science is superior to Horkheimer's critical theory qua supra-empirical meta-science. The debate is one about the bounds within which the critique of scientific practice may take place. For Neurath and other Logical Empiricists, it is clear that there can be no standpoint outside or above scientific practice from which a meta-scientific critique is possible. In other words, critique is only possible 'immanently' (though the metaphysically loaded word would not be in agreement with Neurath's point of view). On the other hand, Horkheimer and other Critical Theorists insisted on supra-empirical Reason as constitutive of the critical standpoint.

Horkheimer and Neurath were, however, as we have seen, in agreement concerning a number of other topics. They both agree on the need to criticize post-war tendencies in Germanophone philosophy, which they both see as politically allied with authoritarianism. Furthermore, they both partly agree that the method of Verstehen has limited applications to

\footnotetext{
${ }^{31}$ It should be noted here that Neurath's conception of the Unity of Science was also centrally preoccupied with the possibility of reflecting on the results of individual sciences from within an empiricist framework; see e.g. Zolo (1989); Uebel (1992: 294-301).
} 
social research, though each has different reasons and agendas in diagnosing these limitations. Finally, despite appearances to the contrary (as I have shown above), both Neurath and Horkheimer in fact agree about the crucial importance of instituting a kind of reflexive critique of scientific activity in light of its social repercussions. Their main disagreement is focused on the positioning of this critical activity in relation to science.

Though the breakdown of the Vienna Circle's attempt to collaborate with the Frankfurt School may have come about largely for extra-philosophical reasons (see Dahms 1994), such methodological disagreements between Horkheimer and Neurath were a contributing factor - at least insofar as they provided an excuse for the breakdown. The opportunity to address such differences through further debate during the late 1930s was missed, alongside the failure of the attempt of the Vienna Circle to collaborate with the Frankfurt School. Instead, the increasingly polemical Frankfurt School criticisms of what its members construed as 'positivism' between the 1940s and the 1960s received no replies from Logical Empiricists. ${ }^{32}$ Since both movements would soon be led into serious philosophical trouble due to upholding the positions in dispute, subsequent debates over the autonomy or immanence of the critique of scientific practice were bound to take very different shapes and forms.

\section{References:}

Adorno, T. W. (1931/1977), “The Actuality of Philosophy”, Telos, 31: 120-33.

Adorno, T. W. (1970/2013), Against Epistemology: A Metacritique: Studies in Husserl and the Phenomenological Antinomies, trans. W. Domingo, Cambridge: Polity.

Adorno, T. W. et al., (1976), The Positivist Dispute in German Sociology, trans. G. Addey and D. Frisby, London: Heinemann.

Arens, K. (2010), “Erklären, Verstehen, and Embodied Rationalities: Scientific Praxis as Regional Ontology", in U. Feest (ed), Historical Perspectives on Erklären and Verstehen, 141-160, Dordrecht: Springer.

Ayer, A. J. (1936/1946), Language, Truth and Logic, 2nd edn, London: Gollancz.

Bowie, A. (2000), “The Romantic Connection: Neurath, The Frankfurt School, and Heidegger, Part two", British Journal for the History of Philosophy, 8(3): 459-83.

\footnotetext{
${ }^{32}$ See also Vrahimis 2020a. Interestingly, Horkheimer's critique of Verstehen as overly subjective is more or less retained by Habermas in the context of the Positivismusstreit in the 1960s (Adorno et. al 1976: 140). One of the theses Popper defended during that debate was that "we cannot reduce to psychology what has often been termed 'verstehende Soziologie' (the sociology of [objective*] understanding)" (Adorno et. al 1976: 102).
} 
Carnap, R. (1931/1959), “The Elimination Of Metaphysics Through Logical Analysis of Language," in A. J. Ayer (ed), Logical Positivism, 60-81, Glencoe, Illinois: The Free Press.

Chase, J. R. (2011), Analytic versus Continental: Arguments on the Methods and Value of Philosophy, Durham: Acumen.

Cooper, D. E. (1996), “Verstehen, Holism and Fascism”, in O'Hear, A. (Ed.), Verstehen and Humane Understanding, Royal Institute of Philosophy Supplement, Vol. 41, 95-107. Cambridge: Cambridge University Press.

Dahms, H-J. (1994), Positivismusstreit, Die Auseinandersetzung der Frankfurter Schule mit dem logischen Positivismus, dem amerikanischen Pragmatismus und dem kritischen Rationalismus, Frankfurt: Suhrkamp.

Damböck, C. (2012), "Rudolf Carnap and Wilhelm Dilthey: 'German' Empiricism in the Aufbau", in R. Creath (ed), Rudolf Carnap and the Legacy of Logical Empiricism, 67-88, Dordrecht: Springer.

Damböck, C. (2017), Deutscher Empirismus. Studien zur Philosophie im deutschsprachigen Raum 1830-1930, Dordrecht: Springer.

Dewulf, F. (2017), "Rudolf Carnap's Incorporation of the Geisteswissenschaften in the Aufbau", HOPOS: The Journal of the International Society for the History of Philosophy of Science, 7 (2): 199-225.

Feest, U. (2007), “'Hypotheses, everywhere only hypotheses!!’: on some contexts of Dilthey's critique of explanatory psychology", Studies in History and Philosophy of Science Part C: Studies in History and Philosophy of Biological and Biomedical Sciences, 38(1): 43-62.

Friedman, M. (2000), A Parting of the Ways: Carnap, Cassirer, and Heidegger, Chicago: Open Court.

Harrington, A. (2001), "Dilthey, Empathy and Verstehen: A Contemporary Reappraisal”, European Journal of Social Theory, 4(3): 311-329.

Hohendahl, P. U. (2010), "The Crisis of Neo-Kantianism and the Reassessment of Kant after World War I: Preliminary Remark", The Philosophical Forum, 41 (1-2): 17-39.

Horkheimer, M. (1933/1972), "Materialism and Metaphysics", in Critical theory: Selected Essays, 10-46, New York: Continuum.

Horkheimer, M. (1937/1972), “The Latest Attack on Metaphysics,” in Critical theory: Selected Essays, 132-87, New York: Continuum. 
Horkheimer, M. (1940), “The Relation between Psychology and Sociology in the Work of Wilhelm Dilthey", Zeitschrift für Sozialforschung, 8: 430-43.

Horkheimer, M. (1947), Eclipse of Reason, Oxford: Oxford University Press.

Horkheimer, M. (2007), A Life in Letters: Selected Correspondence, Lincoln and London: University of Nebraska Press.

Horkheimer, M., and T. W. Adorno (1947), Dialektik der Aufklärung, Amsterdam: Querido. Jay, M. (1996), The Dialectical Imagination: A History of the Frankfurt School and the Institute of Social Research, 1923-1950, Berkeley: University of California Press.

Makkreel, R. (1992). Dilthey: Philosopher of the Human Studies (2nd edition, with afterword), Princeton, NJ: Princeton University Press.

Marcuse, H. (1936/1968), “The Concept of Essence”, in Negations: Essays in Critical Theory, Boston: Beacon.

Nelson, E. (2018), "Dilthey and Carnap: The Feeling of Life, the Scientific Worldview, and the Elimination of Metaphysics", in J. Feichtinger, F. Fillafer, J. Surman (eds), The Worlds of Positivism, 321-346, Cham: Palgrave Macmillan.

Neurath, O. (1921/1973), “Anti-Spengler”, in M. Neurath and R. S. Cohen (eds), Otto Neurath: Empiricism and Sociology, 159-213, Dordrecht: D. Reidel.

Neurath, O. (1931/1973), "Empirical sociology”, in M. Neurath and R. S. Cohen (eds), Otto Neurath: Empiricism and Sociology, 319-421, Dordrecht: D. Reidel.

Neurath, O. (1937a). "Einheitswissenschaft und Logischer Empirismus: Eine Erwiderung”, Unpublished manuscript, Wiener Kreis Archive (203/K.63), Noord-Hollands Archief, Haarlem.

Neurath, O. (1937b). "Inventory of the Standard of Living”. Zeitschrift für Sozialforschung, 6 (1): $140-151$.

Neurath, O. (2011). "Unity of Science and Logical Empiricism: A Reply”, in O. Pombo, J. Symons, J. M. Torres (eds), Otto Neurath and the Unity of Science, 15-30, Dordrecht: Springer.

Neurath, O. (2020a). "Worldview and Marxism (original edition in 1931, translated from German by Alan Scott)", Sociologica, 14(1), 243-248.

Neurath, O. (2020b). “Bourgeois Marxism. A Review Essay on Karl Mannheim, Ideologie und Utopie (original edition in 1930, translated from German by Alan Scott)", Sociologica, 14(1), 235-241.

O’Neill, J., and Th. Uebel (2004), "Horkheimer and Neurath: Restarting a Disrupted Debate”, European Journal of Philosophy, 12 (1): 75-105. 
O’Neill, J., and Th. Uebel (2018), “Between Frankfurt and Vienna: Two Traditions of Political Ecology", in S. Smith and K. Forrester (eds), Nature, Action and the Future: Political Thought and the Environment, 133-156, Cambridge: Cambridge University Press.

Phillips, D. (2010), “Epistemological Distinctions and Cultural Politics: Educational Reform and the Naturwissenschaft/Geisteswissenschaft Distinction in Nineteenth-Century Germany", in U. Feest (ed), Historical Perspectives on Erklären and Verstehen, 15-35, Dordrecht: Springer.

Reisch, G. A. (2005). How the Cold War transformed Philosophy of Science. Cambridge: Cambridge University Press.

Romizi, D. (2012). “The Vienna Circle's ‘Scientific World-Conception': Philosophy of Science in the Political Arena." Hopos: The Journal of the International Society for the History of Philosophy of Science 2 (2):205-242.

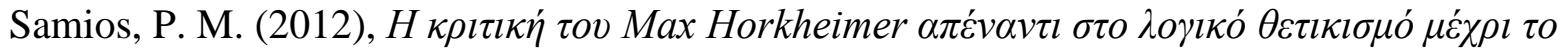

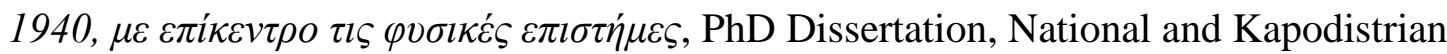
University of Athens.

Scott, A. (2020), Introduction to Otto Neurath's “Bourgeois Marxism” (1930) and “Worldview and Marxism” (1931), Sociologica, 14(1): 227-234.

Stadler, Friedrich. 2015. The Vienna Circle. Studies in the Origins, Development, and Influence of Logical Empiricism. Switzerland: Springer.

Turner, S. P., and R. A. Factor (2014), Max Weber and the Dispute Over Reason and Value: A Study of Philosophy, Ethics and Politics, London: Routledge.

Uebel, Th. (1992), Overcoming Logical Positivism from within: The Emergence of Neurath's Naturalism in the Vienna Circle's Protocol Sentence Debate, Amsterdam-Atlanta, GA: Rodopi.

Uebel, Th. (2007), Empiricism at the Crossroads: The Vienna Circle's Protocol-Sentence Debate Revisited, Chicago: Open Court.

Uebel, Th. (2010), “Opposition to Verstehen in Orthodox Logical Empiricism”, in U. Feest (ed), Historical Perspectives on Erklären and Verstehen, 291-308, Dordrecht: Springer.

Uebel, Th. (2019), "Neurath on Verstehen”, European Journal of Philosophy, 27 (4): 912-38.

Uebel, Th. (2020), "Intersubjective Accountability: Politics and Philosophy in the Left Vienna Circle", Perspectives on Science, 28(1): 35-62.

Vrahimis, A. (2015), "Legacies of German Idealism: From the Great War to the Analytic/Continental divide”, Parrhesia, 1 (24): 83-106. 
Vrahimis, A. (2020a), "Scientism, Social Praxis, and overcoming Metaphysics: A debate between Logical Empiricism and the Frankfurt School", HOPOS: The Journal of the International Society for the History of Philosophy of Science, 10 (2): Forthcoming.

Vrahimis, A. (2020b), "Pragmatism and the History of the Analytic-Continental divide". International Journal of Philosophical Studies, Published online: 27 Aug 2020.

Vrahimis, A. (2020c), “The Vienna Circle's responses to Lebensphilosophie”, Logique et Analyse, Forthcoming.

Wheatland, T. (2009), The Frankfurt School In Exile, Minneapolis: The University of Minnesota Press.

Zolo, D. (1989), Reflexive Epistemology: The Philosophical Legacy of Otto Neurath, Dordrecht: Kluwer. 